\title{
Parameters Affecting the Production of High Carbon Ferromanganese in Closed Submerged Arc Furnace
}

\author{
Mamdouh Eissa*, Hoda El-Faramawy*, Azza Ahmed, Saeed Nabil \\ and Hossam Halfa
}

\author{
Steel and Ferroalloys Department, Central Metallurgical Research and Development \\ Institute (CMRDI), P. O. Box 87, Helwan, Cairo, Egypt, \\ *Corresponding Authors: h3174752@yahoo.com,mamdouh_eissa@yahoo.com
}

\begin{abstract}
This study has been performed to investigate the different parameters affecting on the production of high carbon ferromanganese in closed submerged arc furnace. The analysis of industrial data revealed that using manganese ores with low $\mathrm{Mn} / \mathrm{Fe}$ ratio necessitates higher amount of Mn-sinter in the charge. Using Mn-blend with higher $\mathrm{Mn} / \mathrm{Fe}$ ratio reduces the coke consumption and this leads to reducing the electrodes consumption. The recovery of $\mathrm{Mn}$ ranges between 70 and $80 \%$. Much higher basic slag has slight effect on Mn- recovery. However, as slag basicity increases, the MnO- content of slag decreases. The manganese content of produced HCFeMn depends mainly on $\mathrm{Mn} / \mathrm{Fe}$ ratio of Mn-blend. For obtaining HCFeMn alloy containing minimum 75\%Mn, it is necessary to use Mn-blend with $\mathrm{Mn} / \mathrm{Fe}$ ratio of higher than 6. A model for determination of the amount and composition of off-gases has been derived based on the chemical composition and material balance of the input raw materials and the produced alloy and slag. By using this model, the amount of off-gases was found to increase by increasing both Mn-blend and coke consumption.
\end{abstract}

Key words: Ferromanganese, closed Furnaces, carbothermic reduction, Slag basicity

\section{INTRODUCTION}

At Sinai Manganese Company (SMC), Abu Zenimam, standard high-carbon ferromanganese (HCFeMn) for the domestic and exported markets is smelted in 21 MVA three phase submerged electric arc furnace as closed top unit. The closed top submerged arc furnace has the following advantages comparing with open furnace: less power consumption, kwh/ton and higher productivity. On the other hand, the requirements for ore used in closed top 
furnace are more restricted, e.g. free oxygen must be less than $10 \%$ and less friable ore. Otherwise, crust may be formed leading to occurrence of explosion.

The proper economic production of ferromanganese performance will be improved by selecting the proper raw materials suitable for the closed top submerged arc furnace, applying the best material balance for the raw materials and enhancing the smelting condition. The result will be lower consumption of raw materials, reduced specific energy consumption, good furnace operation, higher alloy quality and lower production cost. Thus, it is of prime importance to examine the different parameters affecting on the production of high carbon ferromanganese in closed submerged arc furnace.

\section{EXPERIMENTAL PROCEDURE}

In the high carbon ferromanganese making process at SMC, different local manganese ores and imported manganese sinter are blended along with the reducing agent (coke) and flux materials (dolomite and limestone) are mixed outside of the furnace (often called charge mix). The different raw materials components are weighed out based on chemical analysis of the ores, sinter, fluxes and coke and on the desired composition of alloy and slag. It is desired to obtain standard high carbon ferromanganese alloy containing at least $75 \% \mathrm{Mn}$ and minimum content of phosphorus.

The raw materials mix is transported to hoppers above the furnace from where it is fed by gravity through chutes passing through the furnace cover.

In the submerged arc furnace, the electrodes are buried deep in the furnace burden and the reduction reaction takes place near the tip of the electrodes. The current flow between electrodes creates the intensive heat needed for the high temperature and energy required for the reduction reactions.

Charge mix is added periodically and the metal and slag are collected during tapping at appropriate intervals (often at $30 \mathrm{Mw}$ ). Produced slag and metal are tapped from the same tap-hole.

\section{RESULTS \& DISCUSSION}

\subsection{Statistical Analysis of Collected Data}

The real operating data for producing high carbon ferromanganese at SMC were collected and statistical analysis of collected data has been conducted to evaluate the different parameters affecting on the production process.

The material balance for producing one ton high carbon ferromanganese has been calculated and an example of the material balance is summarized in Table $\mathbf{1 .}$ 
The electric are steelmaking furnace operates as a batch melting process producing batches of molten steel known "heats". Thus, it is easy to determine the input and output of every heat. On the other hand, the closed top submerged arc furnace for producing high carbon ferromanganese operates by continuous process. The charge mix is added periodically and the metal and slag are collected during tapping at appropriate materials (often every power consumption of $30 \mathrm{Mw}$ ). Consequently, the tapped metal and slag are not the output of input charge mix especially when changing the charge materials composition or if the charge mix is subjected to modification. For that reason, the material balance calculations were done for periods of one month, or periods of some operations days working with constant charge mix.

Table 1: Material balance for producing one ton of HC-FeMn alloy

\begin{tabular}{|c|c|c|c|c|c|c|c|c|c|c|c|c|c|c|c|c|}
\hline $\begin{array}{c}\text { Raw } \\
\text { materials }\end{array}$ & $\mathrm{Kg}$ & $\mathrm{MnO}_{2}$ & $\mathrm{MnO}$ & $\mathrm{Fe}$ & $\mathrm{Fe}_{2} \mathrm{O}_{3}$ & $\mathrm{SiO}_{2}$ & $\mathrm{Al}_{2} \mathrm{O}_{3}$ & $\mathrm{CaO}$ & $\mathrm{MgO}$ & $\mathrm{Na}_{2} \mathrm{O}$ & $\mathrm{BaO}$ & $\mathrm{P}_{2} \mathrm{O}_{5}$ & $\mathrm{C}$ & $\mathrm{CO}_{2}$ & $\mathrm{CO}$ & $\mathrm{H}_{2} \mathrm{O}$ \\
\hline Mn-ore1 & 976 & 458.4 & 206 & & 118.6 & 83.3 & 24.4 & 26.4 & 13.7 & 3.416 & 27.13 & 2.235 & & & & 7.12 \\
\hline Mn-ore2 & 392 & 166.7 & 78.8 & & 68.99 & 43.1 & 9.016 & 8.04 & 3.53 & 1.254 & 5.88 & 0.763 & & & & 2.55 \\
\hline Mn-sinter & 653 & 130.6 & 382 & & 42.9 & 50.4 & 25.47 & 1.96 & 1.18 & 2.612 & 2.612 & 1.137 & & & & 4.83 \\
\hline Dolomite & 245 & & & & 2.132 & 11.9 & 3.185 & 72 & 46.8 & & & & & 107 & & 1.27 \\
\hline Limestone & 140 & & & & 0.742 & 5.74 & 1.022 & 72.2 & 0.98 & & & & & 58 & & 0.56 \\
\hline Coke & 458.3 & & 0.34 & & 7.975 & 23.9 & 17.01 & 1.55 & 0.13 & & & 0.033 & 394 & & & 4.58 \\
\hline Electrodes & 16.9 & & & & & & & & & & & & 16.9 & & & \\
\hline Elect.casing & 0.708 & & & 0.708 & & & & & & & & & & & & \\
\hline Sum & 2882 & 755.7 & 667 & 0.71 & 241.3 & 218 & 80.1 & 182 & 66.3 & 7.28 & 35.62 & 4.17 & 411 & 165 & & 20.9 \\
\hline Kmol & & 8.69 & 9.4 & 0.013 & 1.51 & 3.64 & 0.79 & 3.25 & 1.64 & 0.117 & 0.232 & 0.029 & 34.2 & 3.76 & & 1.16 \\
\hline Products & $\mathrm{Kg}$ & Mn & $\mathrm{Fe}$ & $\mathrm{MnO}$ & $\mathrm{FeO}$ & $\mathrm{SiO}_{2}$ & $\mathrm{Al}_{2} \mathrm{O}_{3}$ & $\mathrm{CaO}$ & $\mathrm{MgO}$ & & & & $\mathrm{C}$ & $\mathrm{CO}_{2}$ & $\mathrm{CO}$ & $\mathrm{H}_{2} \mathrm{O}$ \\
\hline FeMn & 1000 & 752 & 173 & & & & & & & & & & 70 & & & \\
\hline Slag & 690 & & & 129.9 & 5.87 & 182 & 80.05 & 185 & 63.8 & & & & & & & \\
\hline Gases & 1024 & & & & & & & & & & & & & 278 & 725 & 20.9 \\
\hline Losses & 168 & & & & & & & & & & & & & & & \\
\hline Sum & 2882 & 752 & 173 & 129.9 & 5.87 & 182 & 80.05 & 195 & 53.8 & & & & 70 & 278 & 725 & 20.9 \\
\hline Kmol & & 13.67 & 3.09 & 1.83 & 0.08 & 3.03 & 0.78 & 3.48 & 1.35 & & & & 5.83 & 6.32 & 25.9 & 1.16 \\
\hline \multicolumn{5}{|c|}{ Metal composition (\%) } & & \multicolumn{6}{|c|}{ Slag composition (\%) } & & \multicolumn{4}{|c|}{ Gas composition (kmol) } \\
\hline $\mathrm{Mn}$ & $\mathrm{Fe}$ & $\mathrm{C}$ & $\mathrm{P}$ & $\mathrm{Si}$ & & $\mathrm{MnO}$ & $\mathrm{FeO}$ & $\mathrm{CaO}$ & $\mathrm{MgO}$ & $\mathrm{SiO}_{2}$ & $\mathrm{Al}_{2} \mathrm{O}_{3}$ & & $\mathrm{CO}_{2}$ & $\mathrm{CO}$ & $\mathrm{H}_{2} \mathrm{O}$ & \\
\hline 75.2 & 17.3 & 7 & 0.18 & 0.18 & & 18.8 & 0.85 & 26.8 & 9.2 & 26.3 & 11.6 & & 6.32 & 25.9 & 1.16 & \\
\hline
\end{tabular}

\subsection{Effect of Different Parameters}

\subsubsection{Raw Materials}

\subsubsection{Mn-Ores}

Blends of local manganese ores and imported manganese sinter are used at SMC for producing the high carbon ferromanganese. The local manganese ores are law and medium grades with $\mathrm{Mn} / \mathrm{Fe}$ ratio ranges between 3 and 5.5.

Manganese to iron ratio is very important in the ferromanganese production process. $\mathrm{Mn} / \mathrm{Fe}$ weight ratio of 7.5 is required for production standard ferromanganese alloy with $78 \% \mathrm{Mn}$ 
[1]. Furthermore, the local manganese ores vary widely in their content of manganese, iron, silicon, alumina, lime, magnesia, potassium and sodium oxides, barium oxide and phosphorus.

Mixtures of two Mn- ores are usually used to be blend with Mn-sinter. The charged Mn-ores mixture amounts to 890 - $1890 \mathrm{~kg}$ per ton produced alloy (average $1375 \mathrm{~kg} / \mathrm{ton}$ ) with $\mathrm{Mn} / \mathrm{Fe}$ ratio ranges between 3.3 and 5.5 (average 4.08).

\subsubsection{Mn-Sinter}

Mn-sinter is suited for use in ferromanganese furnaces, since it is mechanically strong and thermally stable, allowing the gas to disperse evenly throughout the preheating and prereduction zone. Moreover, the requirements for ore used in closed top furnace are more restricted, i.e. excess oxygen must be less than $10 \%$. To adjust this vital parameter in closed top furnaces, excess oxygen, Mn-sinter is used in the charge mix. Excess oxygen is defined as the difference between the actual amount of oxygen chemically bounded to manganese and the theoretically amount of oxygen assuming the total amount of manganese being present in the monoxide $\mathrm{MnO}$ state.

At SMC, Mn-sinter is used to increase the Mn-Fe ratio of the blend and reduce the excess oxygen. Mn-sinter has a higher Mn /Fe ratio ranges between 9.3 and 12.6, and the charged amount ranges between 385 and $870 \mathrm{~kg}$ per one ton produced ferromanganese alloy (average $642 \mathrm{~kg} /$ ton). This amount represents 22 to $45 \%$ of the Mn- blend (average 32.2\%).

By adding $\mathrm{Mn}$-sinter into the Mn-ores mixture, the Mn /Fe ratio of Mn-blend increases to 4.5 - 6.4 (average 5.4) and the Mn-blend amounts to 1745 - $2430 \mathrm{~kg}$ per ton produced ferromanganese alloy (average $1998 \mathrm{~kg} / \mathrm{ton}$ ).

Furthermore, addition of Mn-sinter reduces the excess oxygen, Figure1. As Mn/Fe ratio of local Mn-ores increases, the Mn-sinter weight per one ton produced HCFeMn decreases, Figure 2, and Mn-sinter\% in the Mn-blend decreases, Figure 3 . 


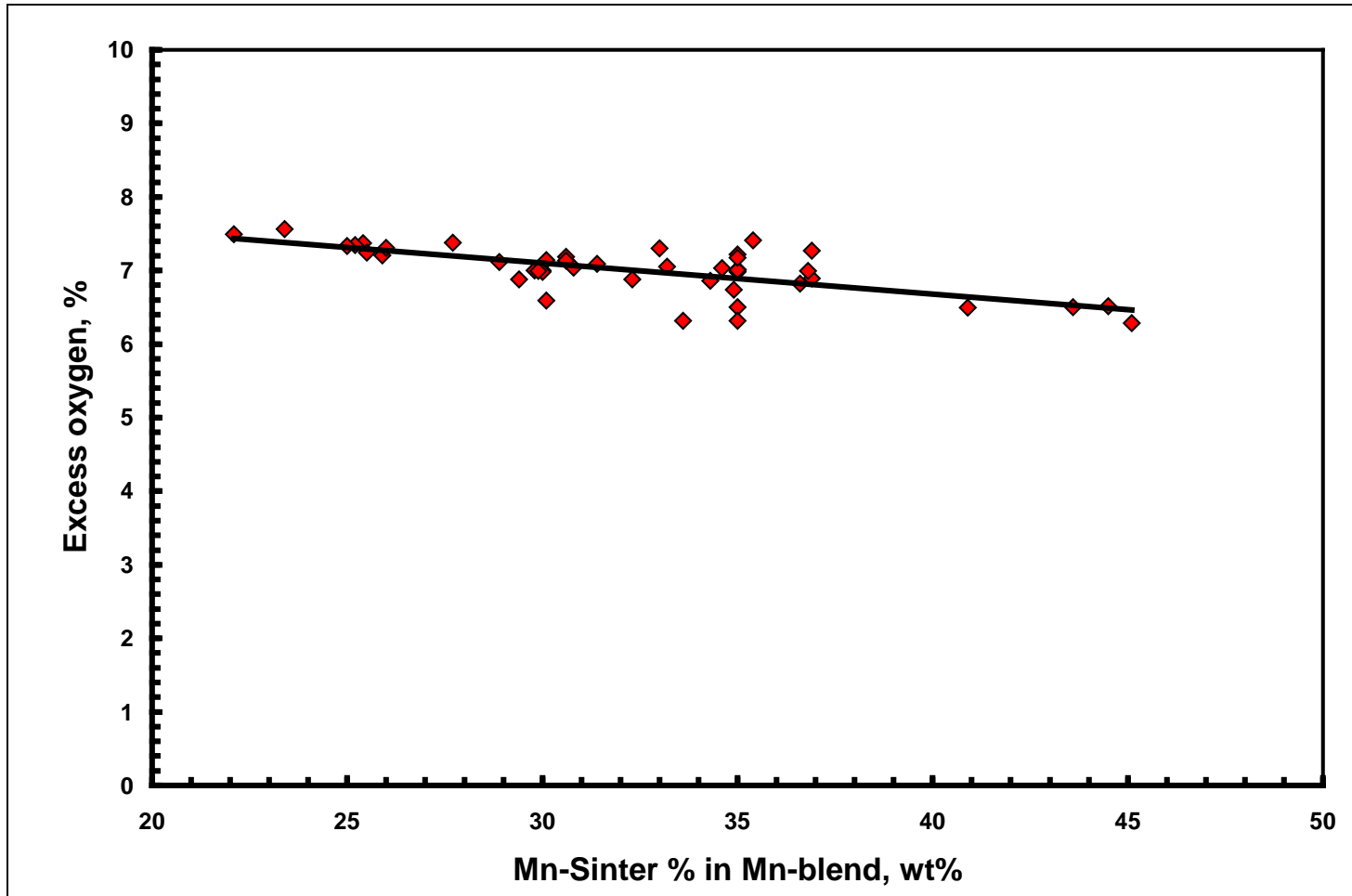

Figure1: Mn-sinter \% in Mn-blend versus excess oxygen

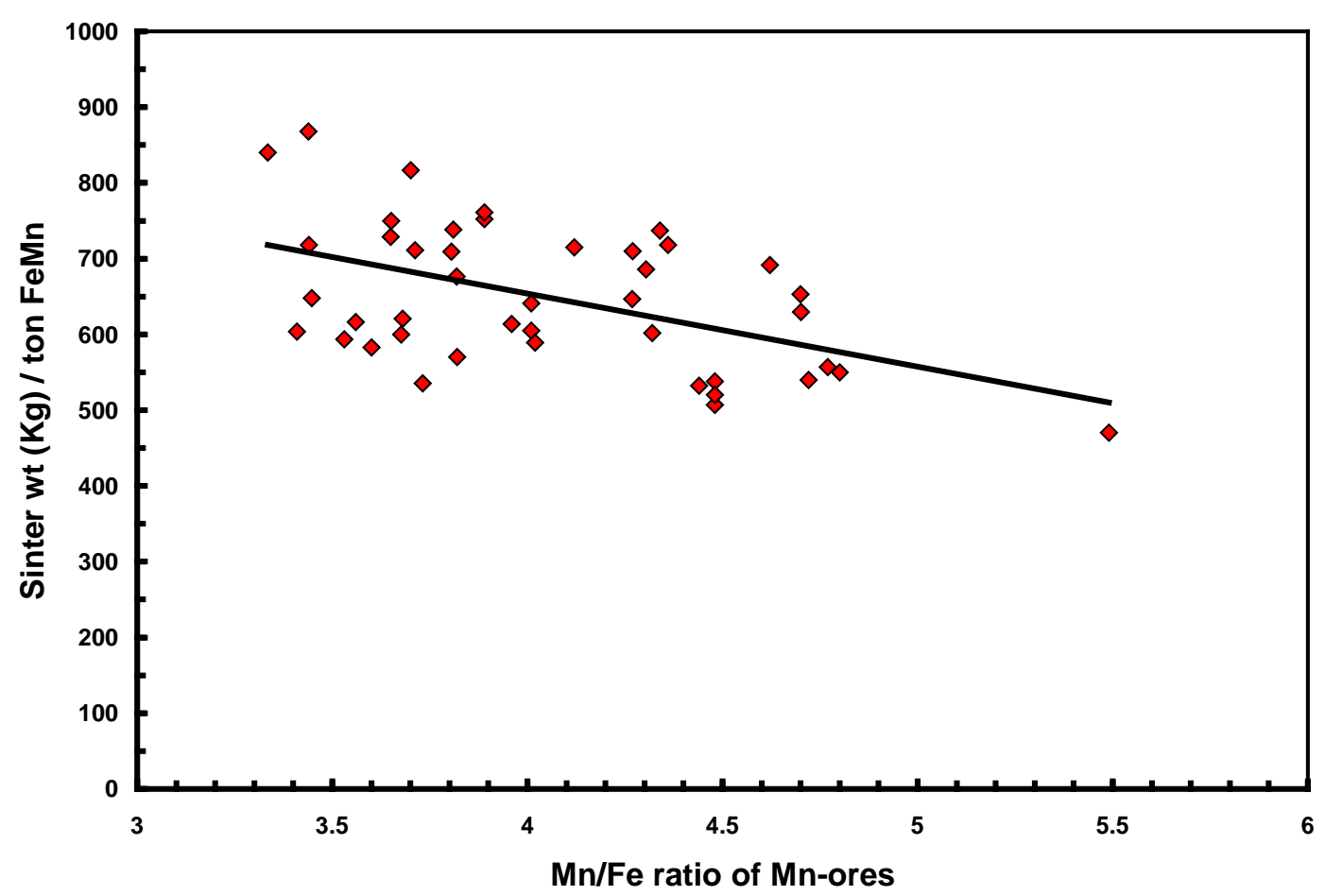

Figure 2: Mn/Fe ratio of Mn-ores versus Mn-sinter wt/ton FeMn 


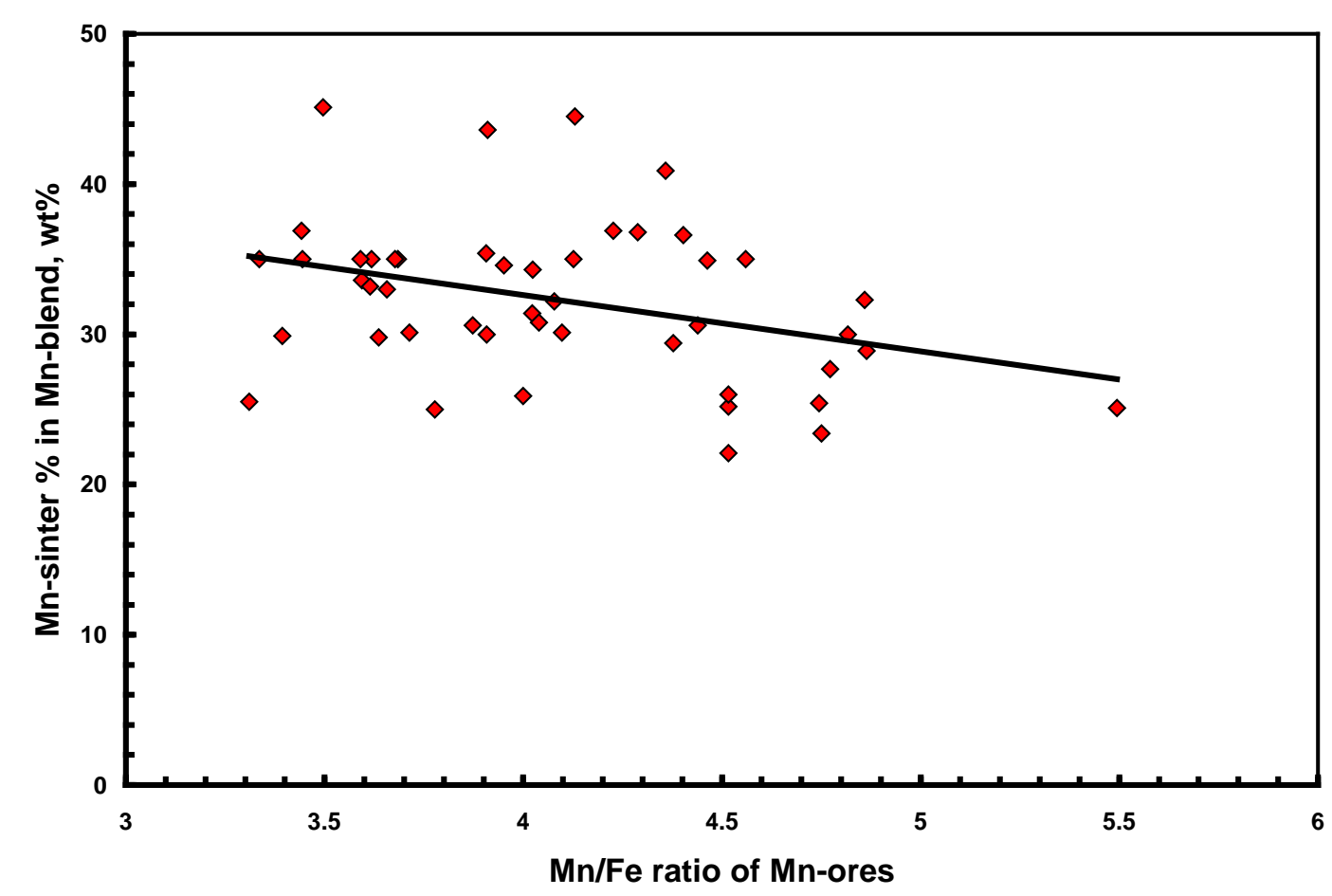

Figure 3: Mn/Fe ratio of Mn-ores versus Mn-sinter\% in Mn-blend

\subsubsection{Reducing Agent}

Coke is added as a source of carbon for ore reduction. The interior of a furnace producing high carbon ferromanganese consists of two main zones with different characteristics: the low temperature pre-reduction zone, and the high temperature coke bed zone. As the raw materials move down in the pre-reduction zone, the higher oxides of manganese are prereduced in solid state to $\mathrm{Mn}_{3} \mathrm{O}_{4}$ and preferably further to $\mathrm{MnO}$ by CO gas formed in the crater zone. The extent of the simultaneously running Boudouard reaction $\left(\mathrm{CO}_{2}+\mathrm{C}=2 \mathrm{CO}\right)$ is responsible for the variation in carbon. After further reheating, the pre-reduced ore and added fluxes start melting at temperatures of about $1250^{\circ} \mathrm{C}$ to $1300^{\circ} \mathrm{C}$. The coke remains solid, so below this area there is a permanent coke bed [2]. The melting together of ores and fluxes and reduction of $\mathrm{MnO}$ dissolved in the slag phase take place in the coke bed. The coke bed starts approximately at the tip of the submerged electrodes. It constitutes a permanent reservoir of coke. The relative amount of coke in the charge mix determines whether the coke bed increases, decreases or stable in size. In addition to being the chemical reductant it is also the heating element of the process where the electric current runs and ohmic energy is produced. The coke consumption ranges between 400 - $550 \mathrm{~kg} /$ ton HCMnFe (average $462 \mathrm{~kg} / \mathrm{ton}$ ). The coke consumption increases as the Mn-blend weight increases, Figure 4, and $\mathrm{Mn} / \mathrm{Fe}$ of the Mn-blend decreases, Figure 5. 


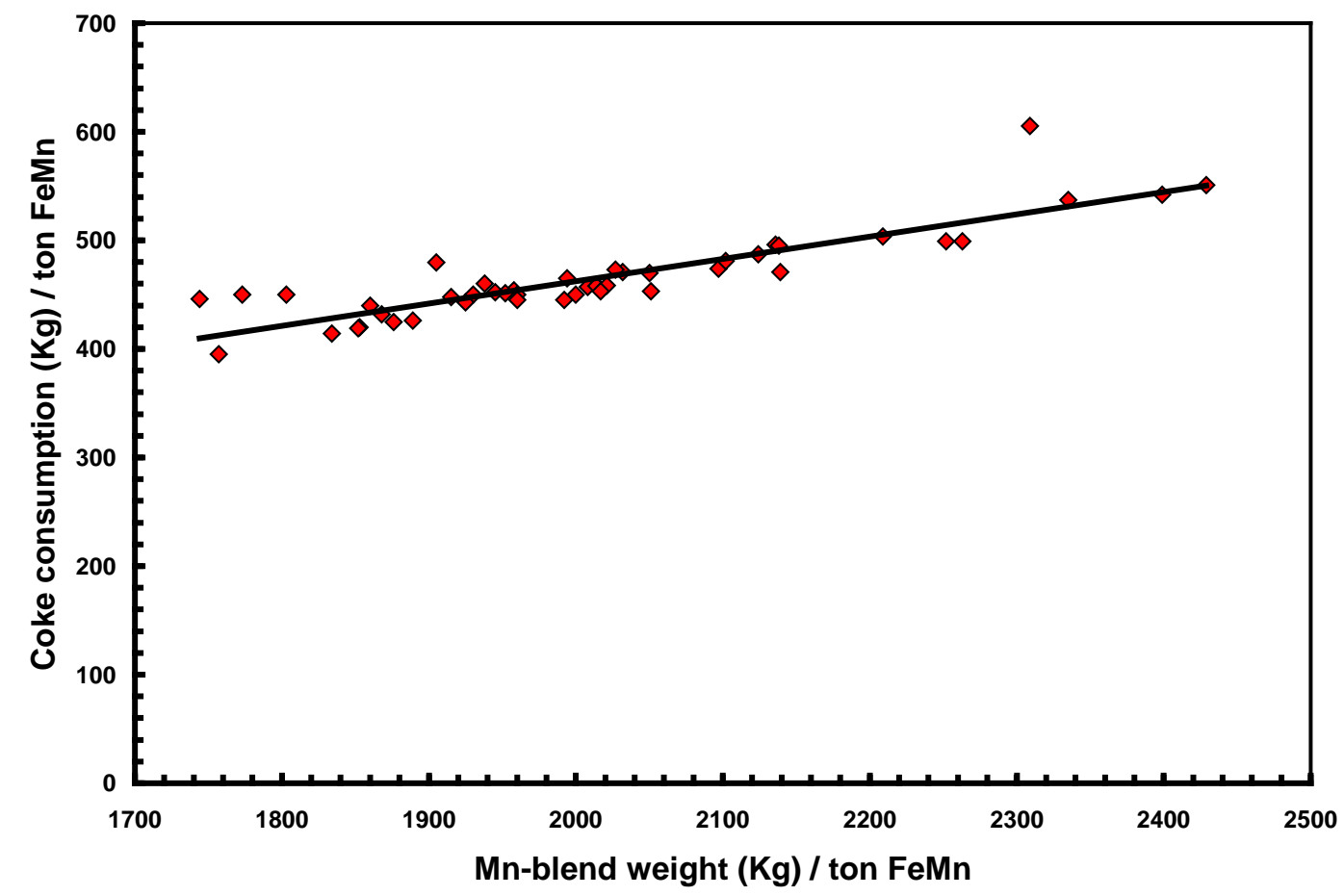

Figure 4 : Mn-blend weight per ton FeMn versus coke consumption

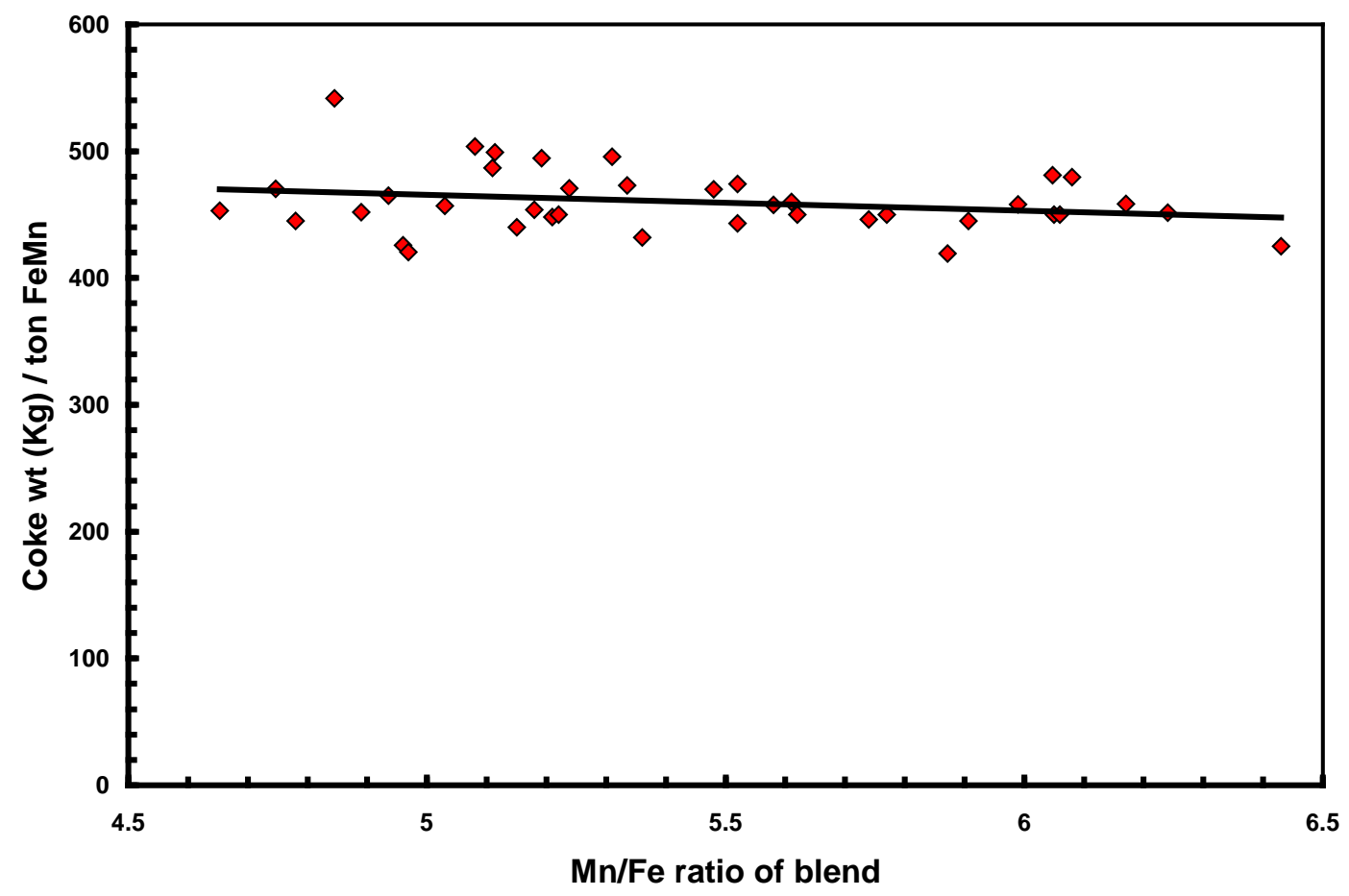

Figure 5: Mn/Fe ratio of Mn-blend versus coke consumption 


\subsubsection{Flux Materials}

Limestone and dolomite are used as flux materials. These basic fluxes are added to give the slag suitable chemical properties, smelting temperature and viscosity in order to secure good furnace operation and a high manganese recovery [1].

The amount of added limestone and dolomite depends on the required $\mathrm{CaO}$ and $\mathrm{MgO}$ to attain the specific slag basicity.

The flux consumption per ton HCFeMn ranges between 200 and $450 \mathrm{~kg}$ (average $340 \mathrm{~kg}$ ). About two third of this amount is dolomite and the other third is limestone.

The flux consumption is correlated with the basicity and $\mathrm{SiO}_{2}$ content of Mn-blend, Figures 6-8 . As the silica amount or percent in Mn-blend increase, the flux addition increases. On the other hand, as the basicity of Mn-blend increases, the flux addition decreases.

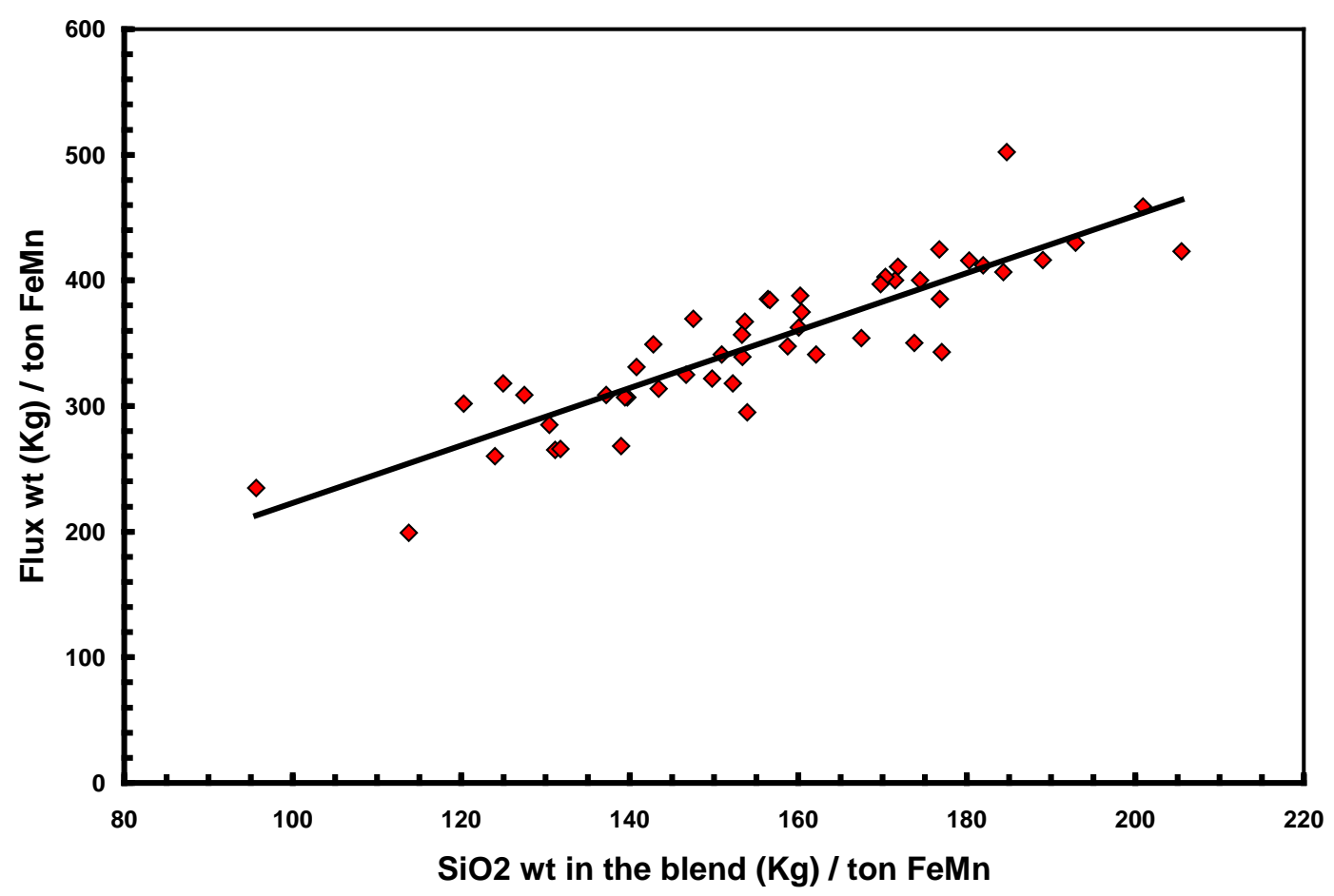

Figure 6: $\mathrm{SiO}_{2}$ weight in Mn-blend per ton FeMn versus coke consumption 


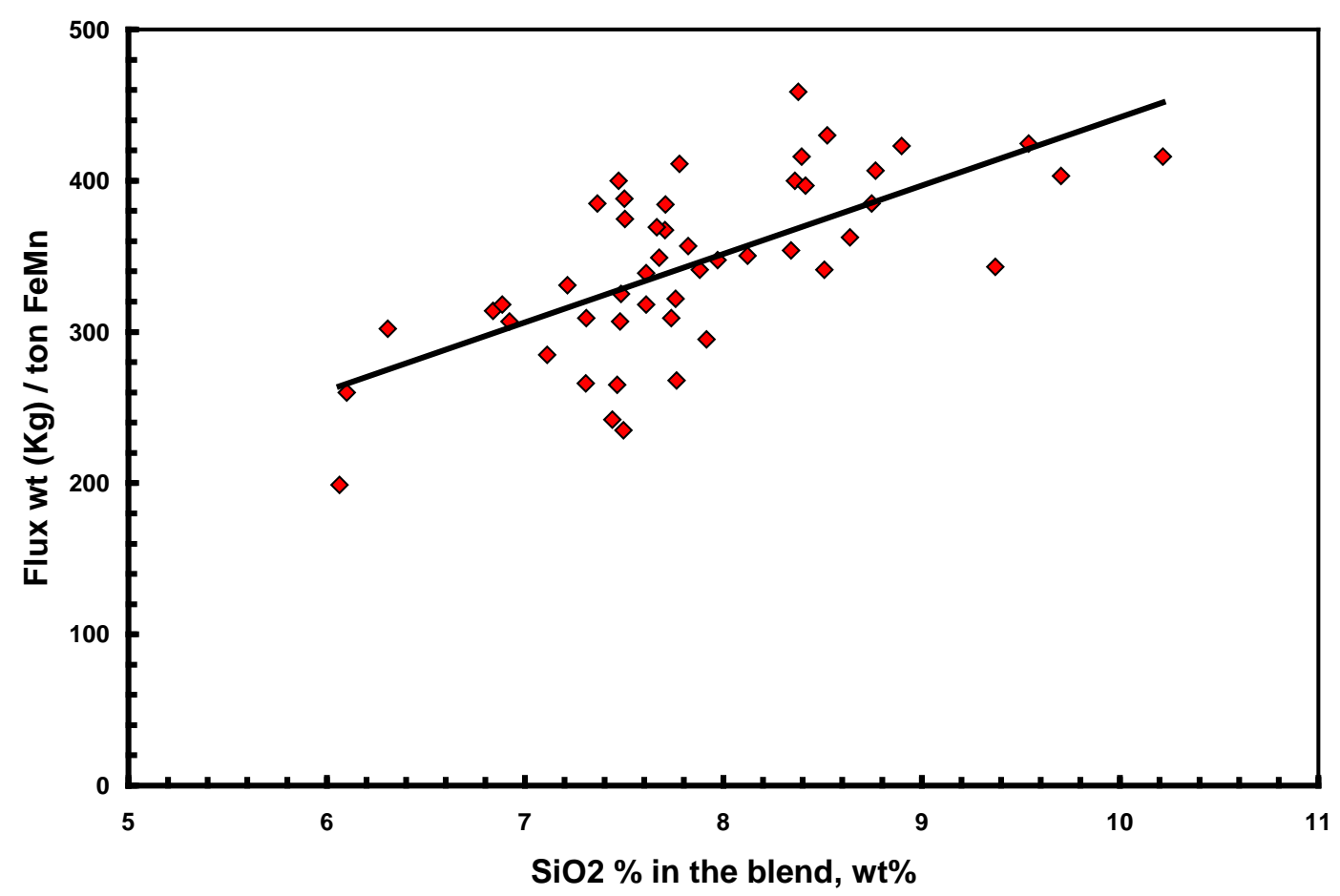

Figure $7: \mathrm{SiO}_{2} \%$ in $\mathrm{Mn}-b l e n d$ versus flux consumption per ton FeMn

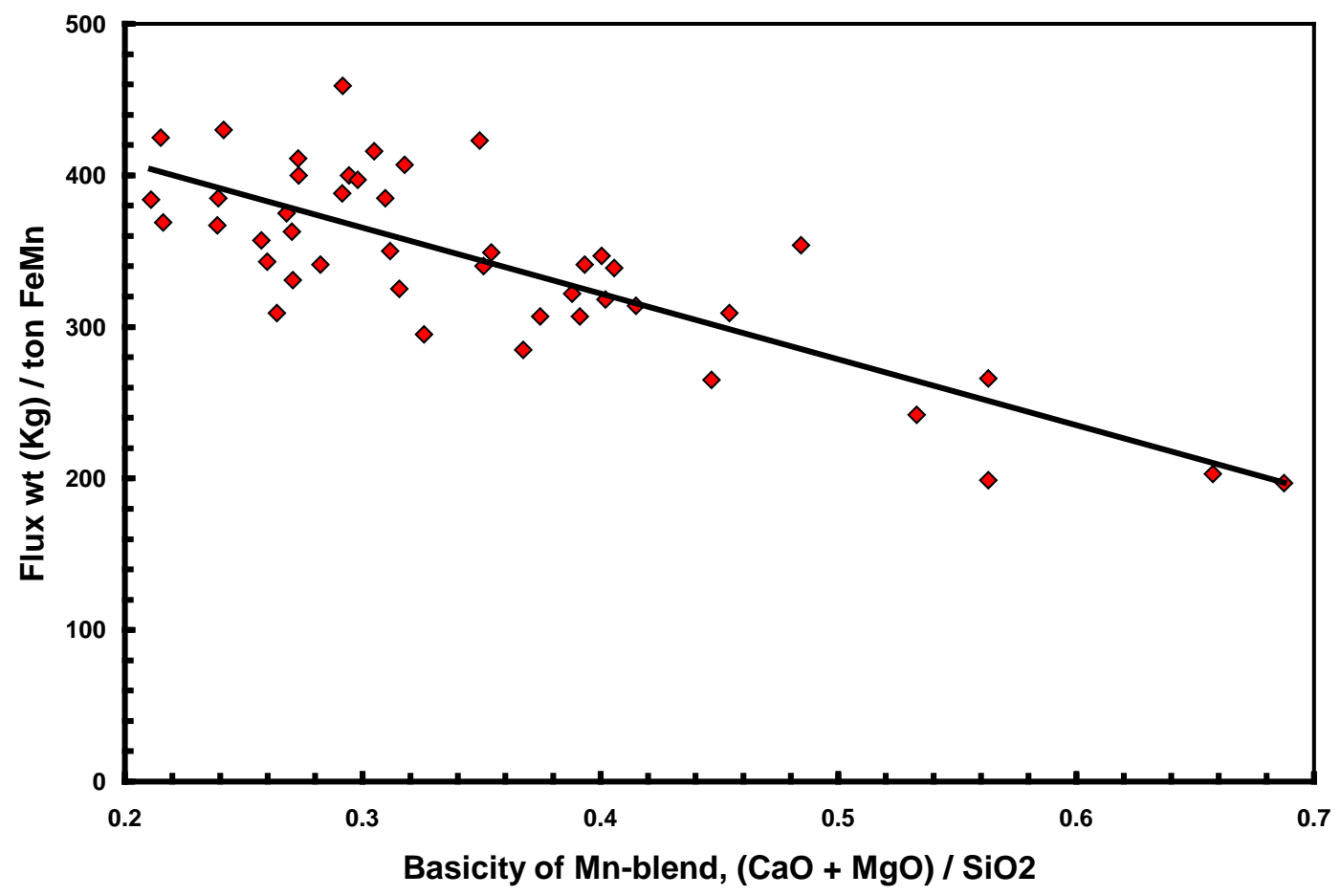

Fig.8: Basicity of Mn-blend versus flux consumption per ton FeMn

\subsubsection{Electrodes}

The electrodes of three-phase electric furnace are made of carbonaceous material, and they consumed during normal production. The consumption is usually large near the tip of the 
electrode where the temperature is high and the reactants are more active. To keep the electrode tip at the same position it is therefore necessary to prolong the electrode regularly. The electrodes consumption per ton HCFeMn ranges between 8 and $37 \mathrm{~kg}$ (average $17.5 \mathrm{~kg}$ ). The electrodes consumption increases as the coke consumption per ton HCFeMn increases, Figure 9.

\subsubsection{Electrodes Casing}

Electrodes casing is a low carbon steel and is consumed with the consumption of electrodes. The electrodes casing consumption ranges between 0.4 and $1.3 \mathrm{~kg} /$ ton HCFeMn (average $0.6 \mathrm{~kg} / \mathrm{ton}$

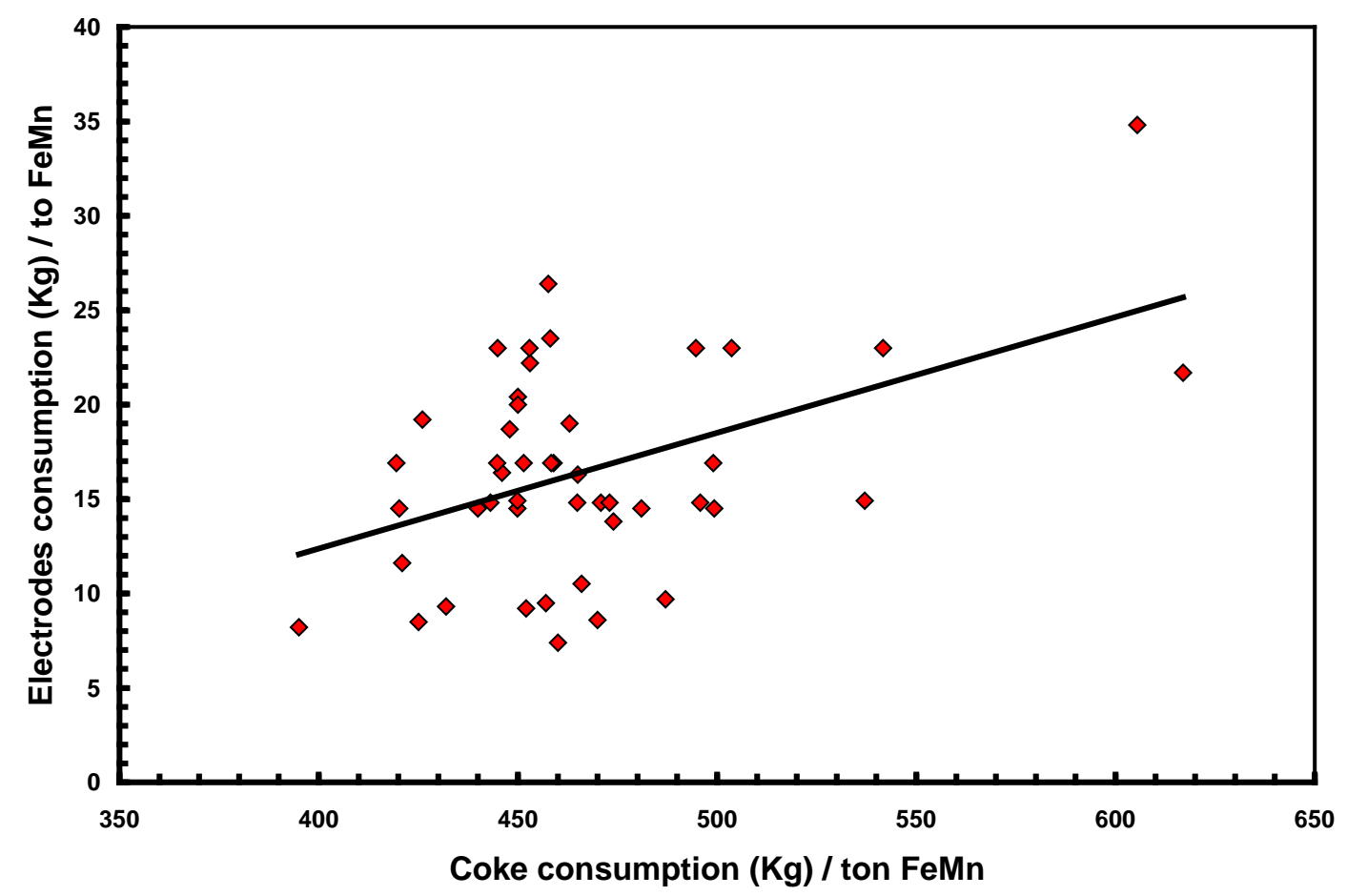

Figure 9: Coke consumption versus electrodes consumption per ton FeMn

\subsection{Products}

\subsubsection{High Carbon Ferromanganese}

The quality of high carbon ferromanganese depends mainly on the content of manganese and phosphorus. The phosphorus content of standard HCFeMn is $\leq 0.2 \%$. Most of the phosphorus in the ore remains in the finished product. The recovery of phosphorus is high (average 98\%) and decreases with increasing the slag basicity as shown in Figure 10. However, due to the relatively low phosphorus content of Mn-blend, the phosphorus content in the produced HCFeMn is low of average $0.18 \%$. The recovery of Mn ranges between 70 and $80 \%$ (average $75 \%$ ). In smelting of high carbon ferromanganese, manganese recovery was found to increase by increasing slag basicity [3-10] and decreasing slag viscosity [5,6]. 
Figure 11 illustrates slight effect of much higher basic slag on Mn- recovery. In the range of the basic slag used, the negative higher viscosity of much higher basic slag [11] hinders the positive effect of increasing the activity of manganese oxide in the slag melt due to existing of higher content of basic oxides $\mathrm{CaO}$ and $\mathrm{MgO}$. The manganese content of produced HCFeMn depends mainly on Mn/Fe ratio of Mn-blend as shown in Figure 12.

For obtaining HCFeMn alloy containing minimum $75 \% \mathrm{Mn}$, it is necessary to use Mn-blend with $\mathrm{Mn} / \mathrm{Fe}$ ratio of higher than 6.

The recovery of iron is higher than the recovery of manganese. Its average is about $96 \%$. In the range of basic slag used, slag basicity has insignificant effect on iron recovery, Figure 13. The silicon content in the metal is very low (average $0.18 \%$ ) as a result of high slag basicity and low operating temperature, leading to low Si recovery of only $2 \%$, Figure 14 .

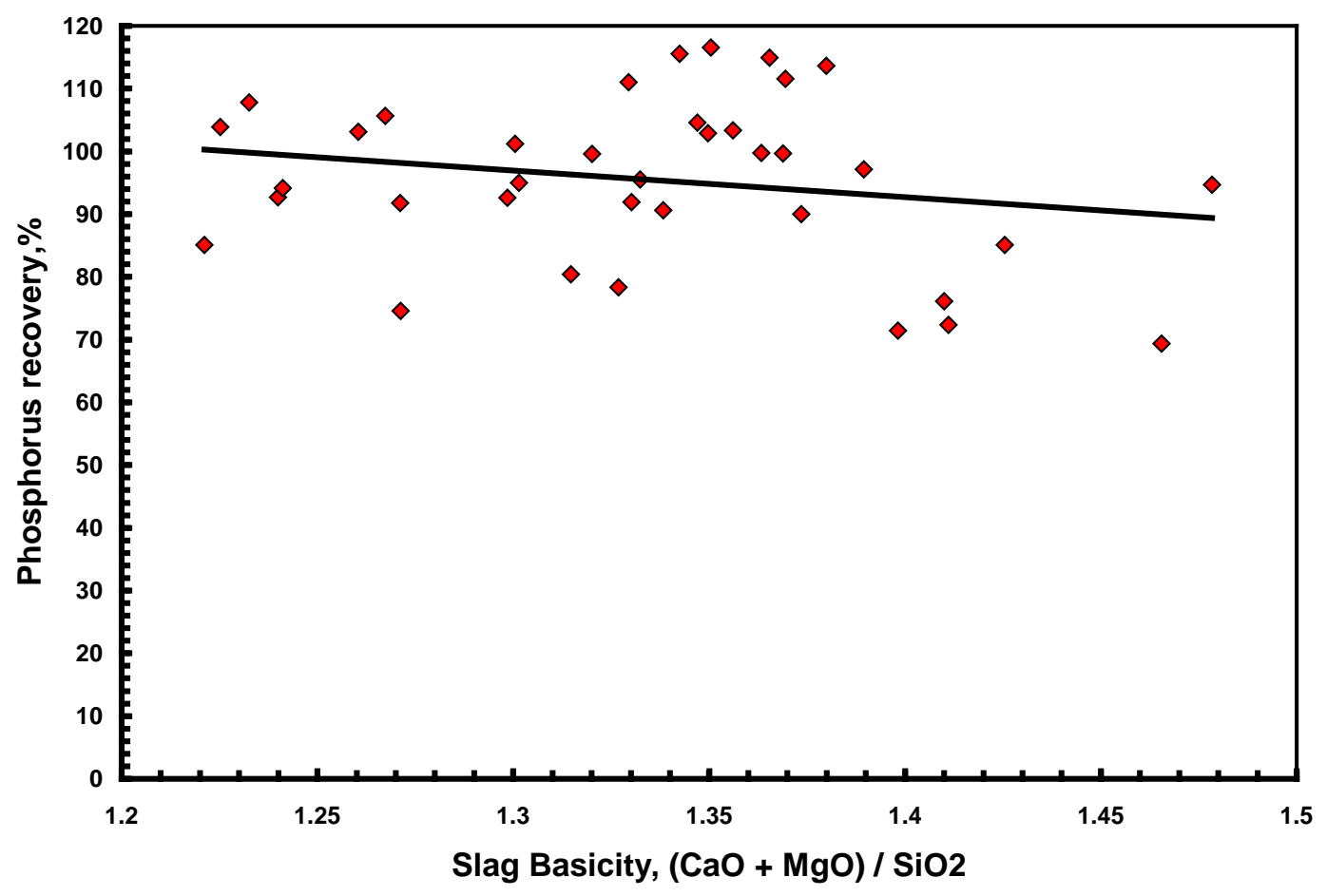

Figure 10: Slag basicity versus phosphorus recovery 


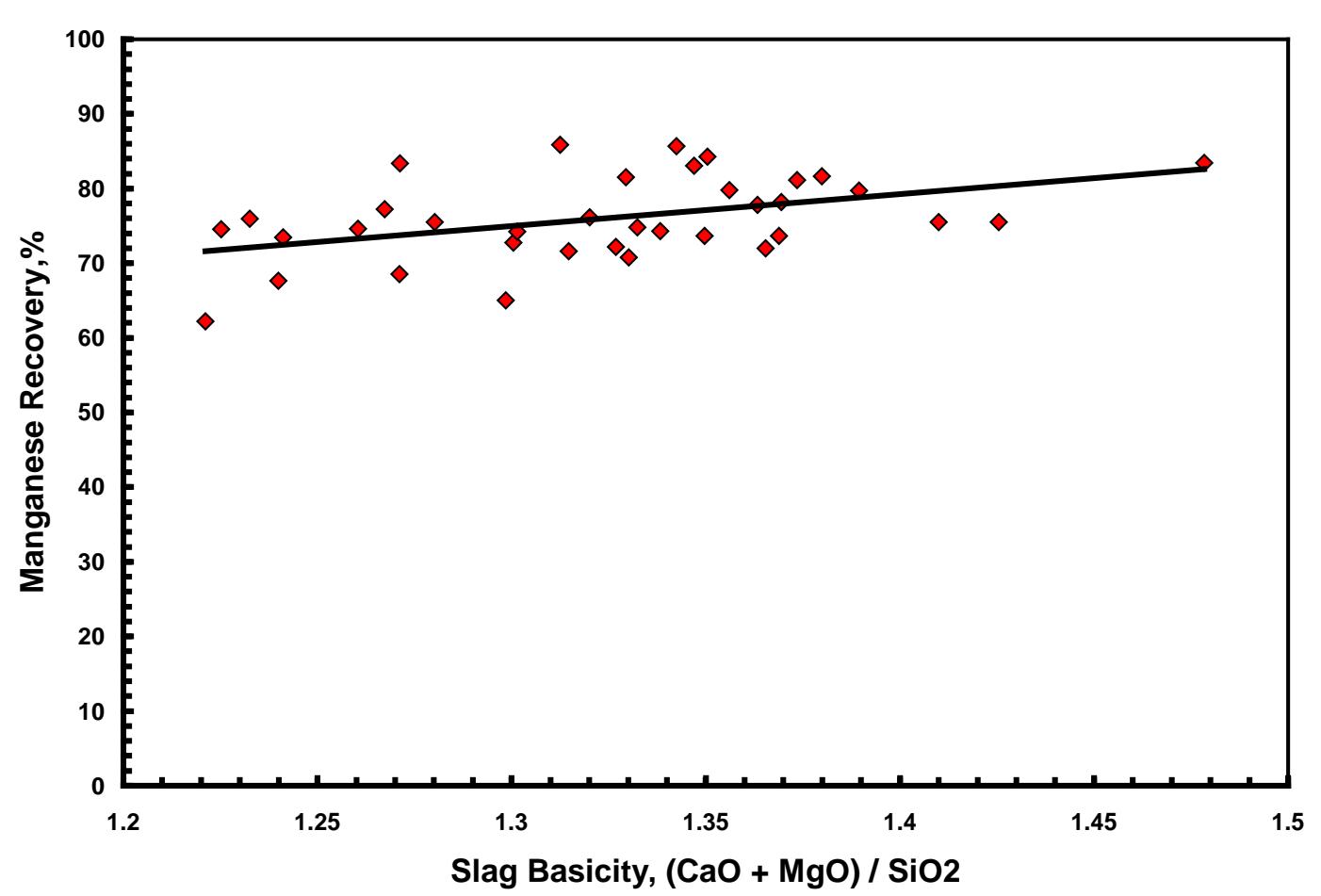

Figure11: Slag basicity, $(\mathrm{CaO}+\mathrm{MgO}) / \mathrm{SiO} 2$, versus manganese recovery

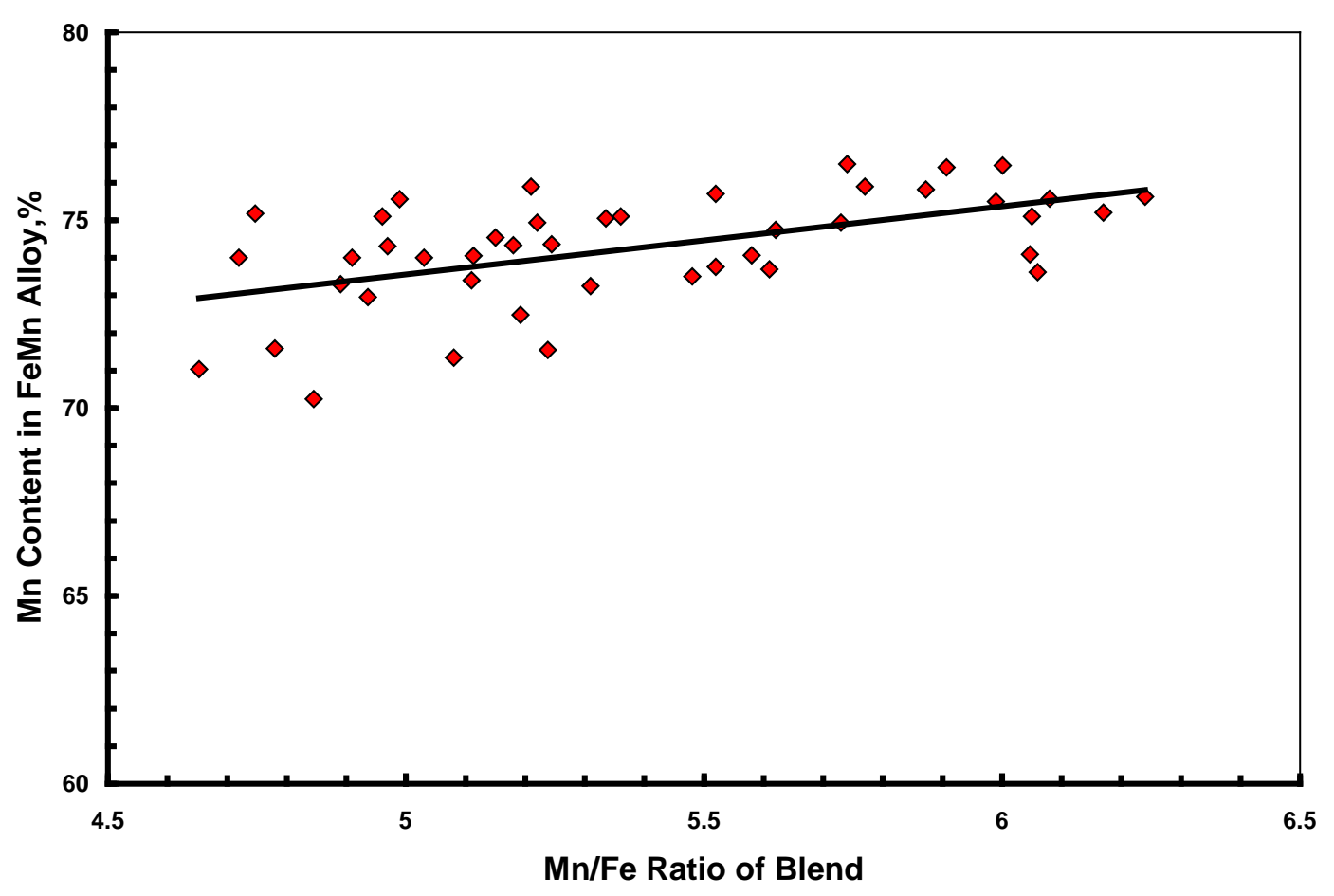

Figure12: Mn / Fe ratio of Mn-blend versus manganese content in FeMn 


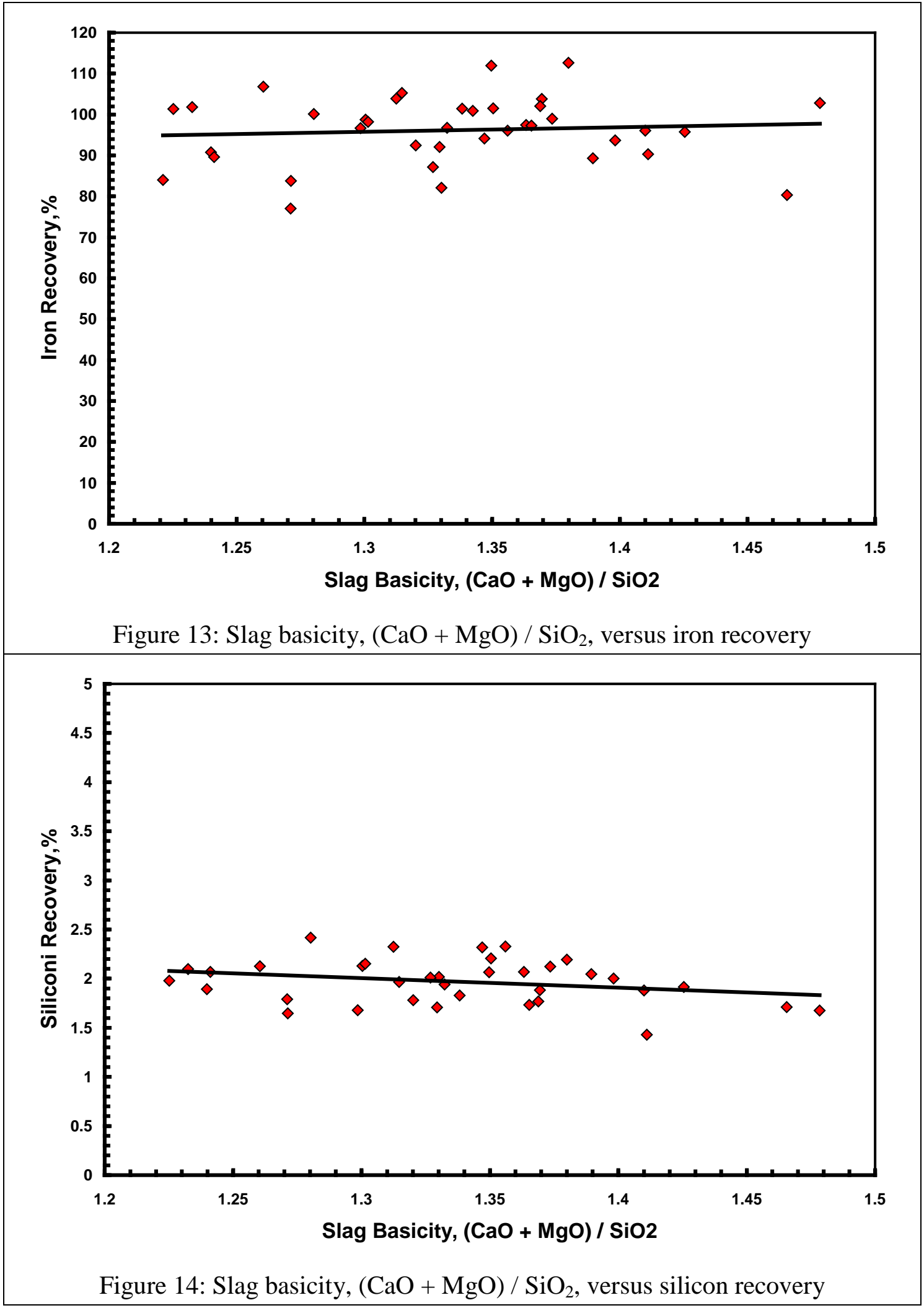

\subsubsection{Slag}

Besides manganese and iron oxide, the manganese ores contain $\mathrm{SiO}_{2}, \mathrm{Al}_{2} \mathrm{O}_{3}, \mathrm{CaO}, \mathrm{MgO}$, $\mathrm{Na}_{2} \mathrm{O}, \mathrm{BaO}$ and $\mathrm{P}_{2} \mathrm{O}_{5}$. Coke ash also contains $\mathrm{SiO}_{2}, \mathrm{Al}_{2} \mathrm{O}_{3}$ and smaller amount of $\mathrm{CaO}$ and 
MgO. In addition, CaO- and MgO- containing fluxes (dolomite and limestone) are added to the raw materials mixture. These oxides will end up in the slag phase.

Most of iron oxides are reduced while Mn-oxides are partially reduced from the slag to form the metal phase. Less $\mathrm{SiO}_{2}$ is reduced because silicon is more stable than $\mathrm{MnO}_{2}$. Even more stable oxides are $\mathrm{CaO}, \mathrm{MgO}$ and $\mathrm{Al}_{2} \mathrm{O}_{3}$. These oxides are considered to be irreducible, and they maintain their mutual ratio in the slag during the reduction process. The amount of slag produced per ton HCFeMn ranges between 460 and $940 \mathrm{~kg}$ (average $661 \mathrm{~kg}$ ).

The amount of slag weight depends on the amount of Mn-blend, Figure 15. This can be attributed to increase of gangue materials and irreducible oxides which enter the slag phase.

In addition, limestone and dolomite are added in the charge mix to adjust the slag basicity. The formula of mass ratio $(\mathrm{CaO}+\mathrm{MgO}) / \mathrm{SiO}_{2}$ is often used to express the slag basicity. As much amount of limestone and dolomite are added the produced slag weight increases, Figure 16.

During the period of collected data, high slag basicity is used to increase the manganese recovery. The $\mathrm{MnO}$-content of slag ranges between 16 and 28\% (average 20\%) depending primarily on slag basicity, Figure 17. As slag basicity increases, the $\mathrm{MnO}$ - content of slag decreases.

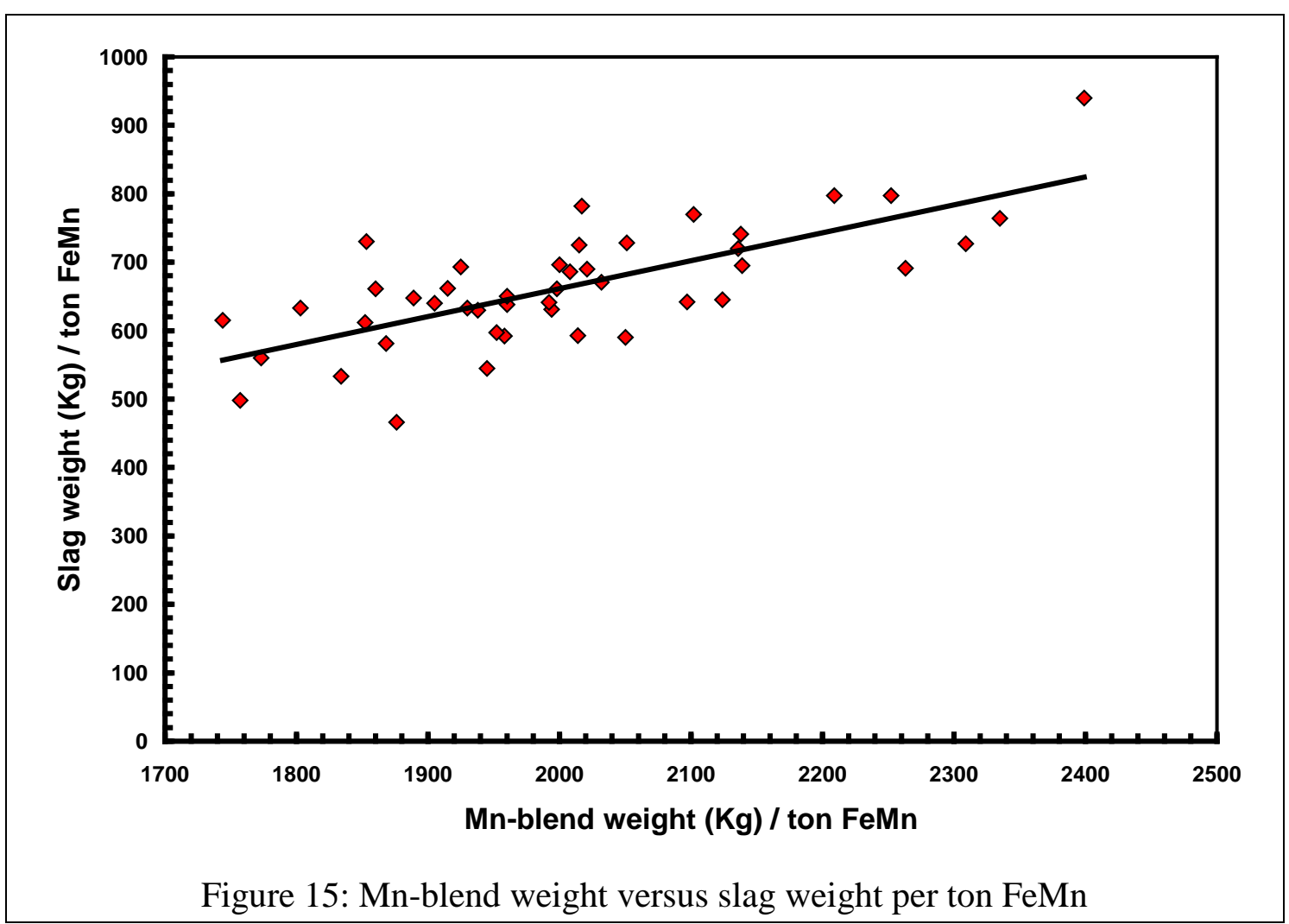




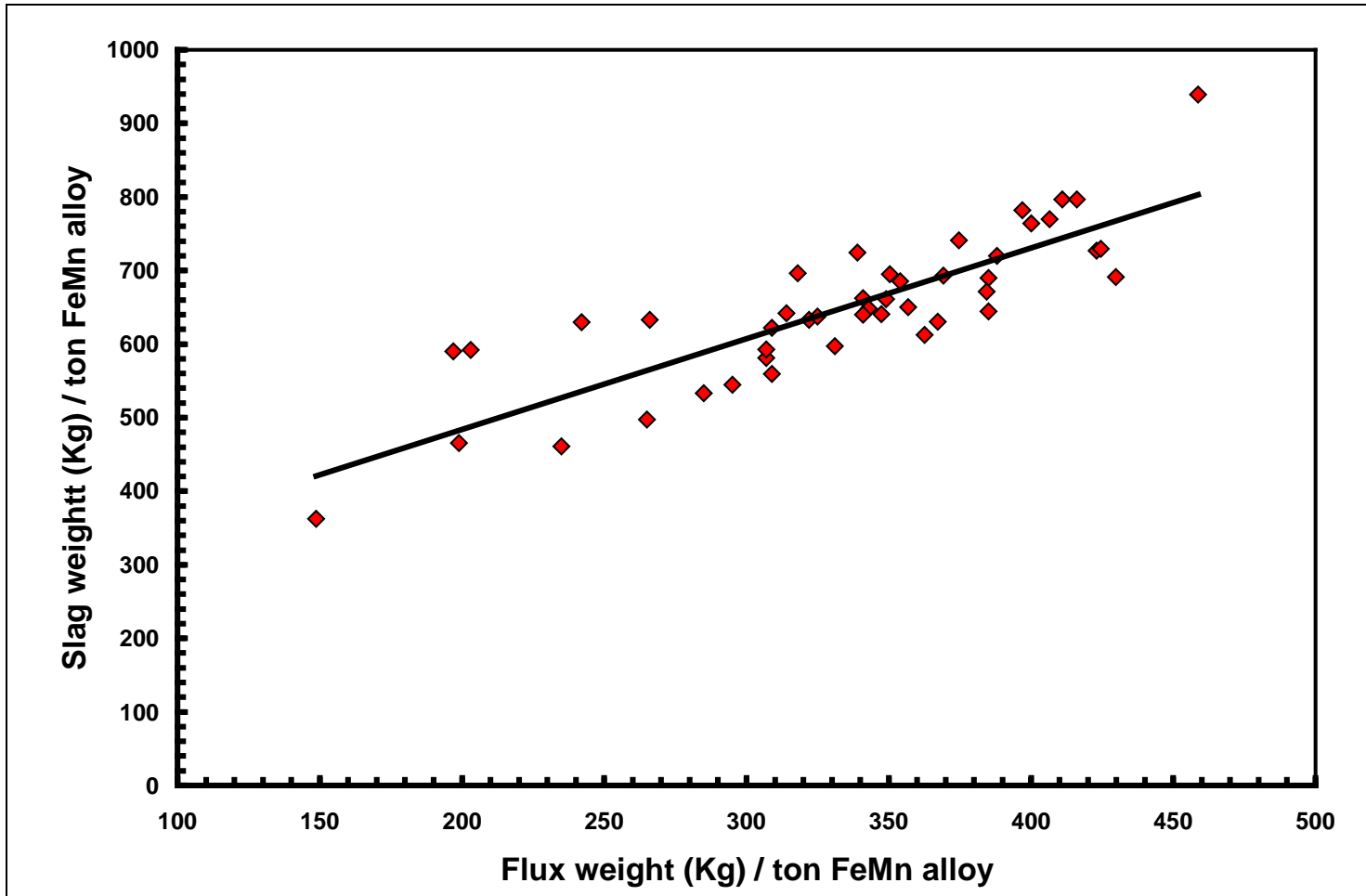

Figure 16: Flux weight versus slag weight per ton FeMn

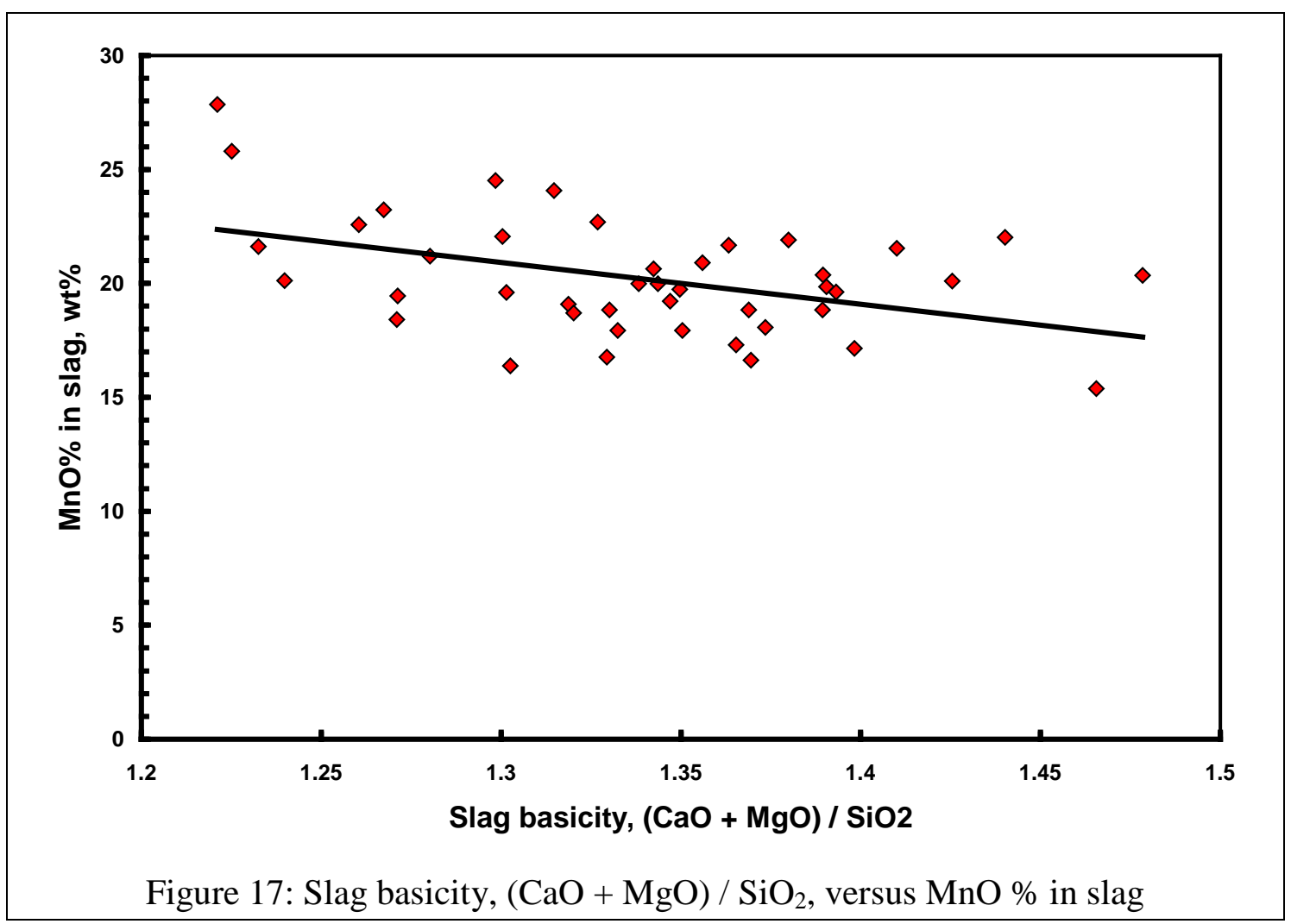




\subsubsection{Gases}

The amount and analysis of the gases leaving the furnace is not available at SMC due to unavailability of measuring devices. Assumptions have been made in order to calculate the amount and composition of the gases. It is assumed that the temperature of the gases at the furnace top, which is in excess of $200^{\circ} \mathrm{C}$, being high enough for evaporation of moisture from charge as soon as the materials fall into the furnace. Evaporation of moisture is very rapid. Thus, all $\mathrm{H}_{2} \mathrm{O}$ (l) enters the furnace leaves as $\mathrm{H}_{2} \mathrm{O}$ (g) with the off-gas.

The other constituents of gas phase are $\mathrm{CO}$ and $\mathrm{CO}_{2}$. By determining the amount of carbon and oxygen in gases, the amount of $\mathrm{CO}$ and $\mathrm{CO}_{2}$ can be calculated.

The carbon amount in $\mathrm{CO}$ and $\mathrm{CO}_{2}$ mixture in off-gas can be calculated by subtraction the carbon contained in the produced HCFeMn from the sum of carbon contained in the added coke, fluxing materials and consumed electrodes,

$\mathbf{C}_{\{\mathrm{CO}+\mathrm{CO}\}}=\mathbf{C}_{\text {(Coke) }}+\mathbf{C}_{\text {(electrodes) }}+\mathbf{C}_{\text {(flux) }}-\mathbf{C}_{\text {(alloy) }}$

The oxygen amount in $\mathrm{CO}$ and $\mathrm{CO}_{2}$ mixture in off-gas can be calculated by subtraction the oxygen contained in the produced slag from the oxygen contained in the raw materials (local Mn-Ores, Mn-Sinter, limestone, dolomite and coke ash),

$\mathbf{O}_{\{\mathrm{CO}+\mathrm{CO} 2\}}=\mathbf{O}_{\text {(Raw materials) }}-\mathbf{O}_{\text {(slag) }}$

The sum of carbon and oxygen in $\left(\mathrm{CO}+\mathrm{CO}_{2}\right)$ mixture equals the sum of $\mathrm{CO}$ and $\mathrm{CO}_{2}$ in offgas:

$\mathrm{C}_{\{\mathrm{CO}+\mathrm{CO}\}}+\mathrm{O}_{\{\mathrm{CO}+\mathrm{CO} 2\}}=\left\{\mathrm{CO}+\mathrm{CO}_{2}\right\}$ in gases

Consequently, the total weight of gases can be calculated:

Gases weight $=\mathrm{CO}+\mathrm{CO}_{2}+\mathrm{H}_{2} \mathrm{O}$

Carbon / oxygen ratio is calculated and correlated with $\mathrm{CO}_{2} /\left(\mathrm{CO}+\mathrm{CO}_{2}\right)$ as shown in Fig (18). The following equation is fitting this relation:

$\mathrm{CO}_{2} /\left(\mathrm{CO}+\mathrm{CO}_{2}\right)$ wt ratio $=-266.67(\mathrm{C} / \mathrm{O})+200$

The amount of gases per one ton HCFeMn ranges between 855 and 1316 $\mathrm{kg}$ (average $1016 \mathrm{~kg}$ ). The $\mathrm{CO}_{2} /\left(\mathrm{CO}+\mathrm{CO}_{2}\right)$ wt ratio ranges between 0.05 and 0.45 (average $0.25)$

Figures (19 -21) reveal increasing the amount of gases per one ton HCFeMn by increasing both Mn-blend and coke and sum of Mn-blend and coke, respectively. This can be attributed to the higher oxygen and carbon in the charge mix. 


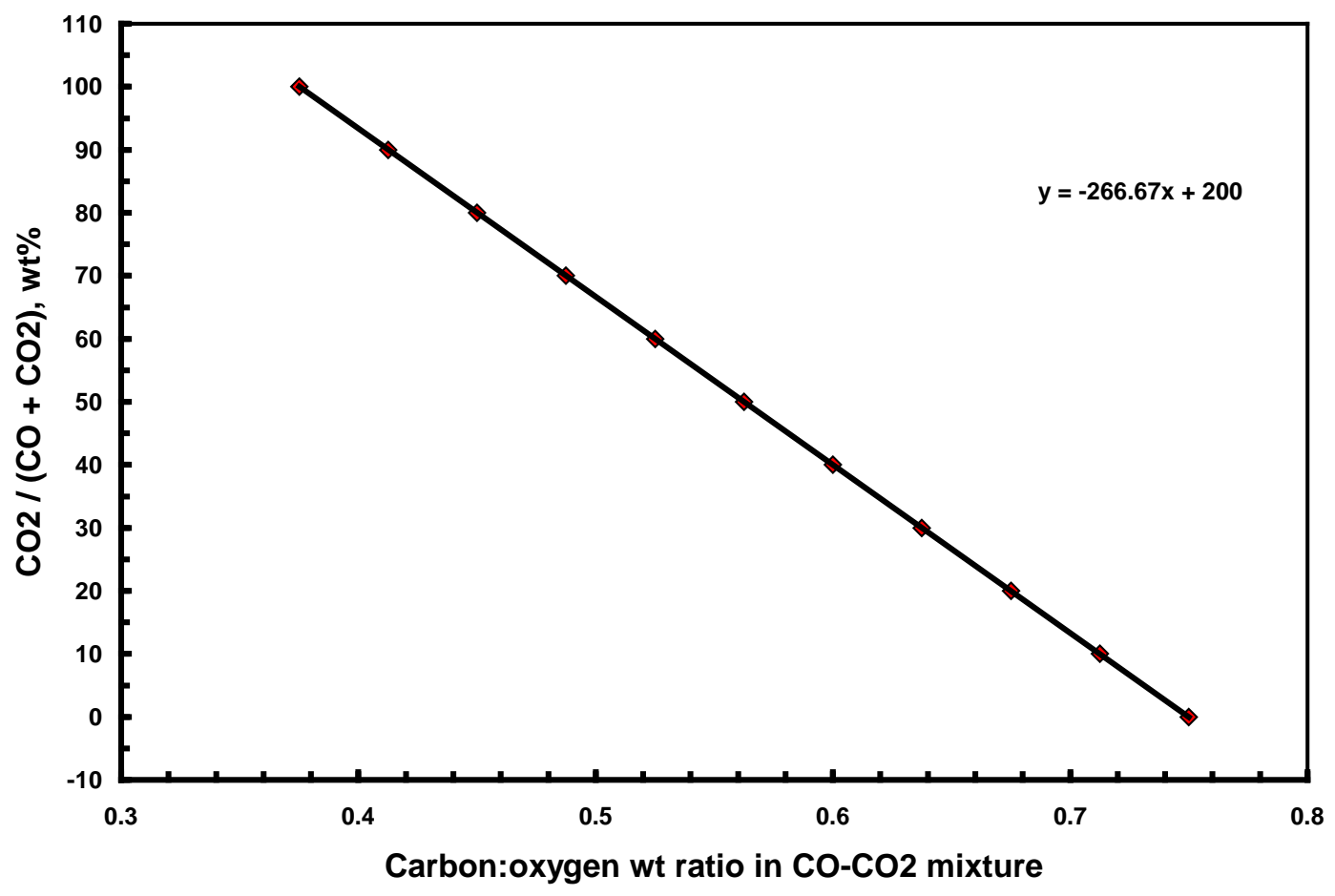

Figure18: Carbon: oxygen ratio versus $\mathrm{CO}_{2} \%$ in $\mathrm{CO}-\mathrm{CO}_{2}$ mixture

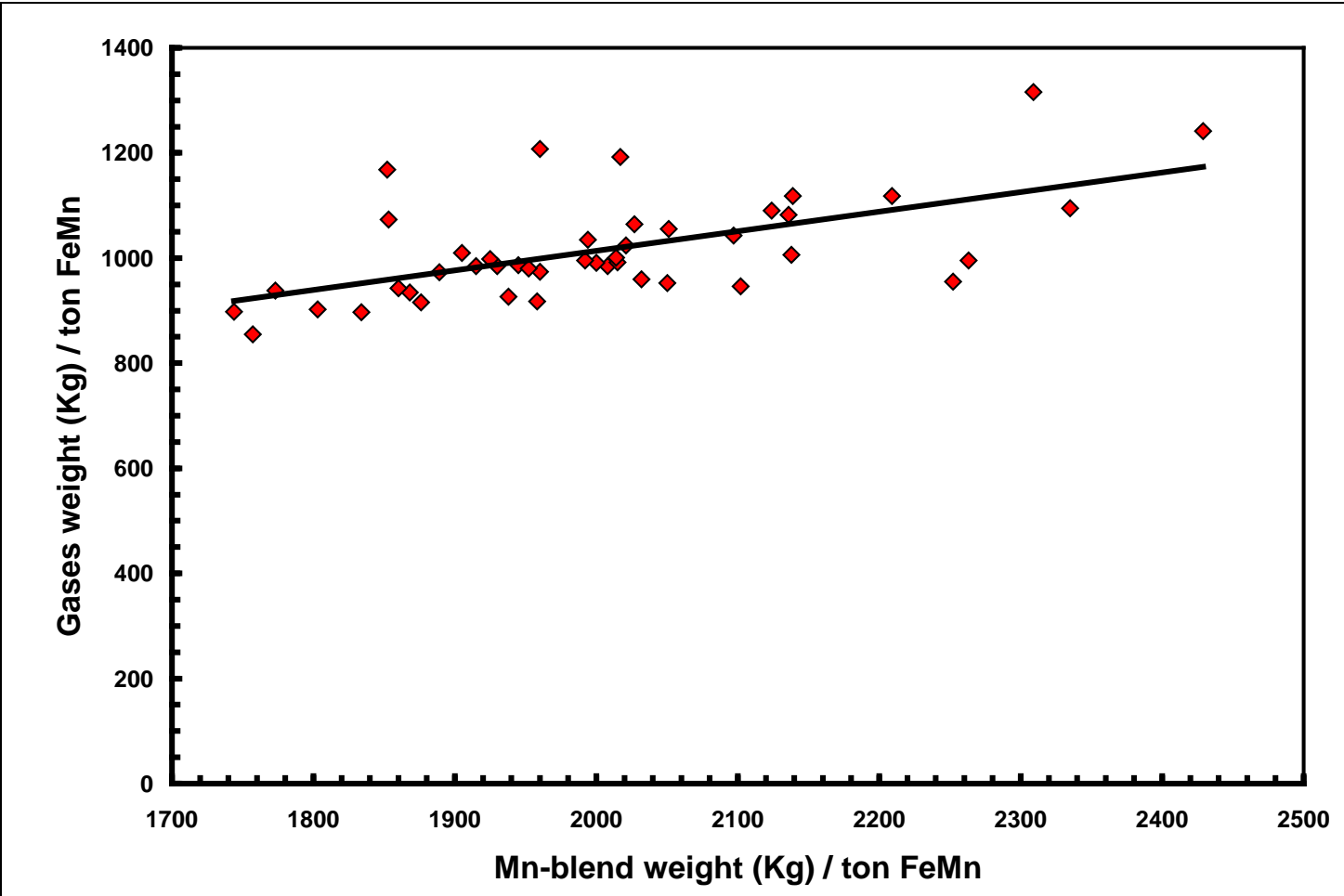

Figure 19: Mn-blend wt versus gases wt per ton FeMn 


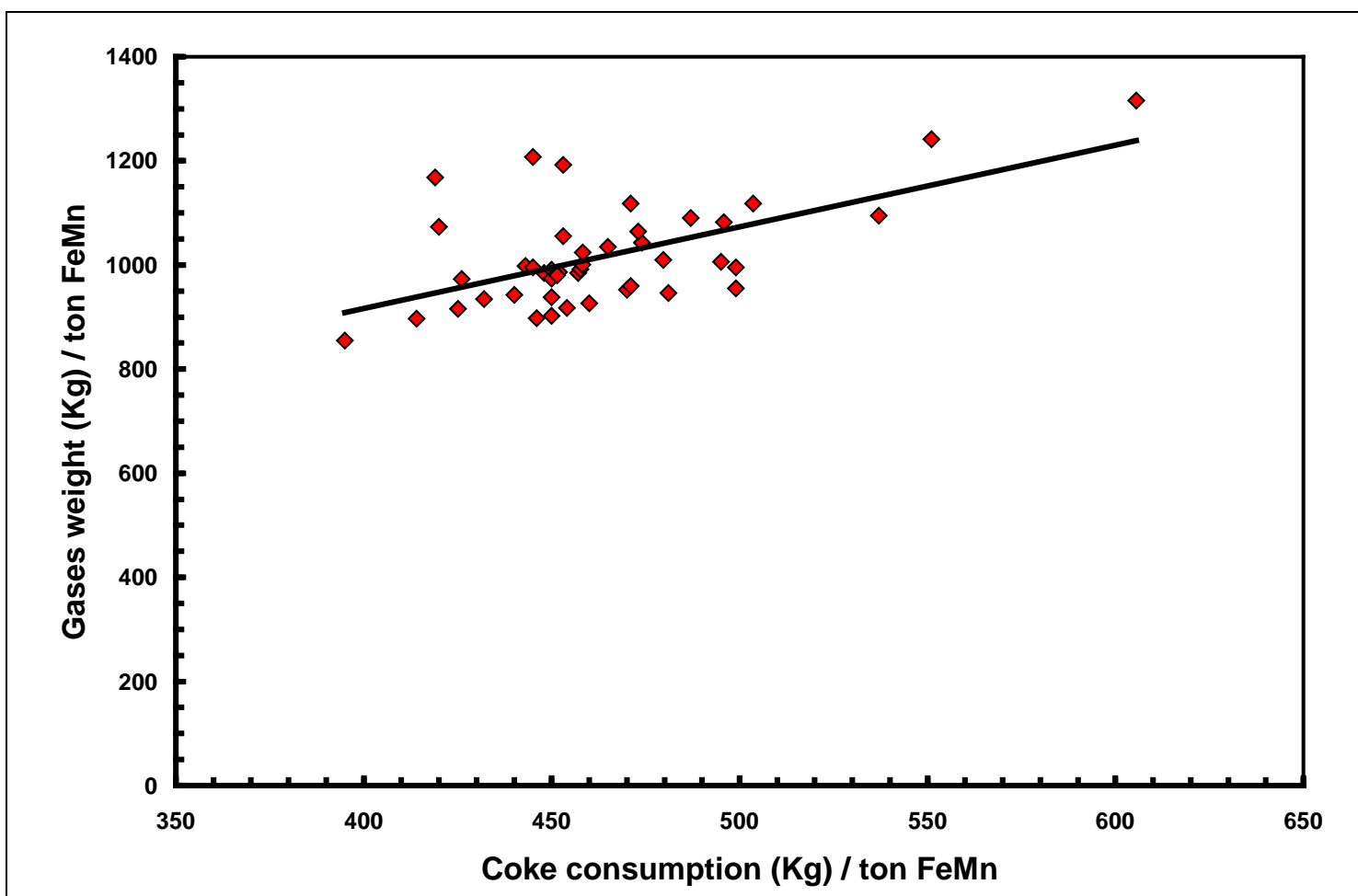

Figure 20: Coke consumption versus gases wt per ton FeMn

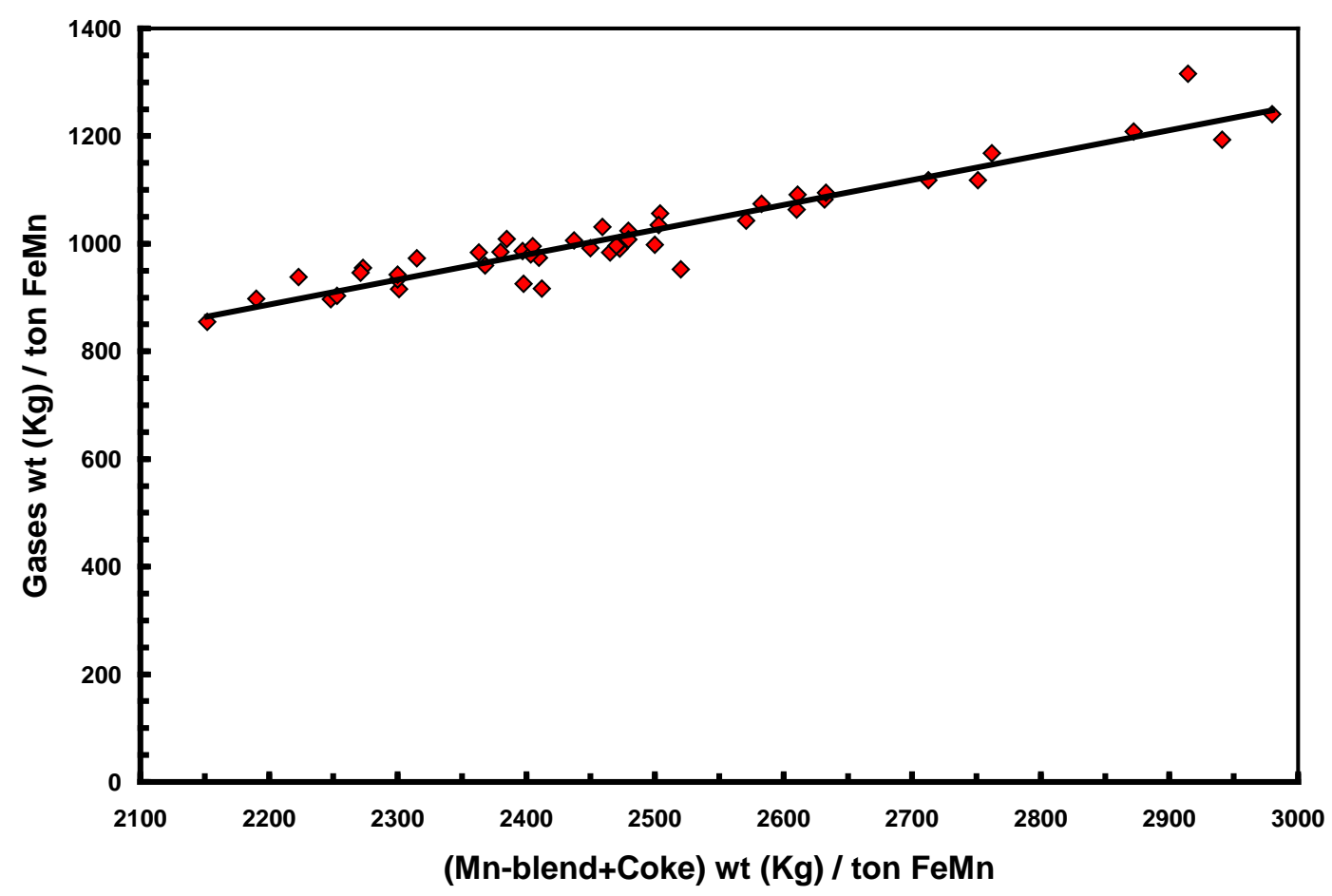

Figure 21: Sum of Mn-blend and coke wt versus gases wt per ton FeMn 


\subsubsection{Losses}

From material balance calculations, weight losses up to $350 \mathrm{~kg}$ per one ton produced HCFeMn has been detected (average $162 \mathrm{~kg}$ ). The average weight losses represent about $5.5 \%$ of the charge mix. These weight losses could be attributed to materials losses in handling and charging process, dust leaving the furnace with the off-gas, weight errors and metal lost in slag and in crushing to the suitable sizes.

\section{CONCLUSIONS}

From the results of analysis of industrial data for producing HC-FeMn in closed submerged arc furnace, the following conclusions can be deduced:

- As Mn/Fe ratio of local Mn-ores increases, the Mn-sinter weight per one ton produced HCFeMn decreases, and Mn-sinter\% in the Mn-blend decreases.

- The coke consumption increases as the Mn-blend weight increases and $\mathrm{Mn} / \mathrm{Fe}$ of the Mn-blend decreases.

- As the silica amount or percent in Mn-blend increase, the flux addition increases. On the other hand, as the basicity of Mn-blend increases, the flux addition decreases.

- The electrodes consumption increases as the coke consumption per ton HCFeMn increases.

- Most of the phosphorus in the ore goes to the finished product. The recovery of phosphorus is high of about $98 \%$ and slightly decreases with increasing the slag basicity. For producing standard HCFeMn containing $\leq 0.2 \% \mathrm{P}$, charging of Mnblend with low phosphorus content is required.

- The recovery of Mn ranges between 70 and $80 \%$. Much higher basic slag has slight effect on Mn- recovery. The negative higher viscosity of much higher basic slag hinders the positive effect of increasing the activity of manganese oxide in the slag melt due to existing of higher content of basic oxides $\mathrm{CaO}$ and $\mathrm{MgO}$.

- The manganese content of produced HCFeMn depends mainly on Mn/Fe ratio of Mnblend. For obtaining HCFeMn alloy containing minimum $75 \% \mathrm{Mn}$, it is necessary to use Mn-blend with $\mathrm{Mn} / \mathrm{Fe}$ ratio of higher than 6.

- The recovery of iron is higher than the recovery of manganese. Its average is about $96 \%$. In the range of basic slag used, slag basicity has insignificant effect on iron recovery.

- The silicon content in the produced alloy is very low (average $0.18 \%$ ) as a result of high slag basicity and low operating temperature, leading to low Si recovery of only 2 $\%$.

- The amount of produced slag depends on the amounts of Mn-blend and fluxing materials.

- The MnO-content of slag depends primarily on slag basicity, as slag basicity increases, the MnO- content of slag decreases. 
- A model for determination of the amount and composition of off-gases has been derived based on the chemical composition and material balance of the input raw materials and the produced alloy and slag.

- The amount of off-gases increases by increasing both Mn-blend and coke amounts.

- In the production process, about $5.5 \%$ of the charge mix weight is lost due to materials losses in handling and charging process, dust leaving the furnace with the off-gases, weight errors and metal lost in slag and in crushing to the suitable sizes.

\section{ACKNOWLEDGEMENT}

This work is a part of complex study carried out through a project financed by the Science and Technological Development Fund (STDF), Egypt. The authors would like to acknowledge STDF due to their financial support and all facilities they offered to perform this work. Cordial thanks and deep appreciation are due to Eng. Mohamed Abdel Samie Chairman \& Managing Director of Sinai Manganese Company (SMC), for his encouragement, sound support and providing technical data. The counterparts of SMC offered all facilities and required data for performing this study. Special thanks and gratitude are due to all members in Steel and Ferroalloys Department, CMRDI and technical staff of SMC Company.

\section{REFERENCES}

[1] Olsen S. E., Tangstad M. and Lindstad T., 2007, Production of Manganese Ferroalloys, P. 247, SINTEF and Tapir Academic Press, Trondheim

[2] Tangstad M. , 1996, The High Carbon Ferromanganese Process-Coke Bed Relations, PhD Thesis, 49, Department of Metallurgy, The Norwegian Institute of Technology, Trondheim

[3] V.I. Nikoleav, 1974, Steel in the USSR, pp. 299-302

[4] N. Chernyatin, V. G. Mizin, I.A. Kopyrin and E. A. Simonova, 1981, Stal, 9, pp. 38-44

[5] Y. Kamel, T. Miyazaki, H. Yamaoka, 1993, ISIJ International, 33 , No.2, pp. 259-266

[6] X. Bi et al, 1993, Ironmaking and Steelmaking, 20, No. 6, pp.476-481

[7] P.A.Kravchenko et al, Steel in Translation, 38(2008), No. 9, pp. 764-760

[8] V.P. Vorob'ev, A. D. Godunov and V. Ignat'v, 2009, Steel in Translation, 39, No.3, pp.243-247

[9] R. Kononov, O. Ostrovski and Ganguly, 2009, ISIJ International, 49, No.8, pp. 10991106

[10] V.Tathavadkar, V.Singh, P.K.Mishra, P. Mallick and B. D. Nanda, 2010, Ironmaking and steelmaking, 37, No. 2, pp.103-111.

[11] Slag Atlas, 1981, Ed. Verein Deutscher Eisenhuttenleute, Verlag Staheisen GmbH, Dusseldorf, p. 282. 